\title{
A Call for Social Work Intervention to Address the Phenomenon of Child Sexual Abuse Against Learners in South African Schools: A Review of the Literature
}

\author{
Daniel Tuelo Masilo ${ }^{1}$ \\ ${ }^{1}$ Lifestyle Research Entity, North West University (Mahikeng Campus), Republic of South Africa \\ Correspondence: Daniel Tuelo Masilo, Department of Social Work, North West University, (Mahikeng Campus), \\ Republic of South Africa. Tel: 27-18-389-2872. E-mail: Tuelo.Masilo@nwu.ac.za
}

Received: September 18, 2019 Accepted: October 8, 2019 Online Published: October 15, 2019

doi:10.5539/gjhs.v11n12p152 URL: https://doi.org/10.5539/gjhs.v11n12p152

\begin{abstract}
Child sexual abuse (CSA) is undoubtedly one of the social problems negatively affecting children in South Africa. Everyday reports in research and different media platforms such as radio, television, social media and newspapers suggest that sexual abuse of children and those attending school, has reached unprecedented proportions. Within the school setting, it is reported that school-based employees such as teachers, security personel and gardeners are alleged to be the perpetrators of this heinous crime against children. The purpose of this paper through the literature review methodology, is to highlight the phenomenon of CSA perpetrated against learners in the South African schools and indicate how the social work profession may intervene. To this end, this paper calls social workers to intervene by means of educating learners on child sexual abuse, establishing and strengthening the childcare and protection forums, engaging parents, guardians and lastly facilitating dialogues with the school-based employees. These interventions will go a long way in addressing the phenomenon of CSA, and most importantly, protecting the rights of children as the most vulnerable group in societies.
\end{abstract}

Keywords: child sexual abuse, learners, schools, social work, South Africa

\section{Introduction}

Child sexual abuse (CSA) is undoubtedly one of the social problems negatively affecting children in South Africa. Everyday reports in research and different media platforms such as radio, television, social media and newspapers suggest that sexual abuse of children and those attending school, has reached unprecedented proportions. According to Rule (2017), one in every three children is sexually abused before the age of 18 . The Minister of Police in South Africa, Mr. Bheki Cele in his brief to the Parliament on 12 September 2019, pointed out that of the reported sexual assaults, 46.5\% were against children during the 2018/19 financial year (Nicolson \& Mafolo, 2019). These statistics may be even higher since not all the cases of sexual abuse against children are reported due to the non-disclosure by children, and this may also be due to the fact that the perpetrators threaten children. Although in some instance's learners report sexual abuse allegations to the school authorities, these learners are ignored and as such their cases do not reach the police authorities. A classical case of a learner that was ignored by the school principal after reporting sexual abuse was noted in the Gauteng province of South Africa (Phagane, 2019).

It is noted in this paper that no single reason can justify why children have and continue to be sexually abused. According to Masilo (2018a, p.341), the myth that having sex with a virgin and a child reverses HIV/AIDS makes children vulnerable to sexual abuse. A similar observation was made in a study conducted in the Eastern Cape Province of South Africa, where it was found that men who sexually abuse children believe that they will get healed from HIV if they have sex with a child (Zantsi, 2014, p.25). In Masehela's (2011, p.73) study conducted in the Limpopo province, one of the reasons learners gave for engaging in sexual activities with teachers was for preferential treatment. According to them, teachers pay the ones who give in, with various incentives; and administer corporal punishment to the ones who refuse to give in to their sexual demands (Masehela, 2011, p. 73). These findings are without any doubt confirmation that teachers are abusing their position of power by sexually abusing learners, knowing very well that sexual relations with learners is prohibited.

Due to the ongoing incidents of sexual abuse perpetrated against learners in schools, Coetzee (2018) is of the view 
that the state should be held liable. It is important to indicate that holding the state liable especially by suing the state will have dire consequnces for the state financially, taking note of the declining economic climate in South Africa and elsewhere in the world. To this end, the question that needs to arise is "what may be done in order to prevent the state to be held liable for the incidents of sexual abuse of learners perpetrated by the school-based employees?" The author of this paper submits that the state through social workers, can contribute to the prevention of sexual abuse through various social work interventions that will not only focus on learners, but also on parents and the school-based employees. It is in this light that this paper calls for social work intervention to address the phenomenon of CSA against learners in the South African schools. In support of this call, Muchacha and Mthetwa (2015, p. 132) state that social workers have a critical role to play in the prevention of CSA. Dube (2016, p.73) adds that social work has devoted maximum efforts towards ameliorating human suffering and reducing conditions and circumstances that bring unhappiness to humanity through professional interventions. Social workers are key players in the maintenance of any nation's social fabric as well as protection of vulnerable members of society (Muchanyerei, 2017). Therefore, it can be argued that social work is duty bound to intervene in addressing the phenomenon of CSA in communities and schools.

\section{Aim of the Study}

The aim of this paper is to highlight the phenomenon of CSA perpetrated against learners in South African schools and make a call on how the social work profession can intervene in addressing this atrocious crime against children.

\section{Method}

This paper is a product of literature on CSA in schools and social work. Literature was reviewed from various sources such as journal articles, dissertations and theses, newspaper reports, books and government reports. Different keywords such as child sexual abuse, learners and sexual abuse and also social work intervention were used to search the literature.

\section{Discussions}

\subsection{Sexual Abuse of Learners in South African Schools}

Sexual abuse of learners' incidents are realities that continues to make news headlines in South African schools. The Member of the Executive Council (MEC) for the Department of Education in the Gauteng Province, Mr. Panyaza Lesufi indicated that 70 cases of sexual violence against learners were reported since the beginning of the 2019 academic year (The Citizen, 2019). In the same province of Gauteng, Seleka (2019) reports that a teacher was suspended for sexual assault of learners at a primary school. In the KwaZulu Natal Province, four teachers in the same school were suspended for allegedly having sex with learners (Singh, 2016). While research conducted in the Limpopo Province found that a male teacher was accused of inviting girl learners to his cottage, showing them pornographic videos and ordering them to perform actual intercourse like the ones on the video (Masehela \& Pillay, 2014). It appears that sexual abuse of learners is not only experienced in public or government schools, but private schools have their own share. For instance, Ngqakamba (2019) indicates that a 9-year-old boy was raped in the bathroom of a Curro Academy school in the North West Province of South Africa. The above-mentioned cases depict the state of affairs in terms of sexual abuse perpetrated against learners in schools, and without any doubt necessitates urgent interventions that will not only focus on learners, but also school-based employees and as well as parents.

\subsection{Effects of Sexual Abuse on Children}

The question of wether sexual abuse has effects on children does not arise, and it is an uncontested reality that there are short- or long-term effects on children who the victims are ultimately. Scott (2006) opines that child sexual abuse is a precursor to child prostitution. According to Markwei and Osei-Hwedie (2019), some victims of CSA may never be able to bear children while others may find it difficult to overcome the trauma associated with the abuse. The possibility of perpetrators infecting children with sexually transmitted diseases including HIV/AIDS cannot be ruled out. It is therefore of paramount importance that children should be educated on the subject of CSA so that in instances whereby they are sexually abuse, they can disclose to the relevant people as early as possible. The early disclosure of sexual abuse will enable children to get necessary assistance such as being taken to the medical facilities for medical examination and also to the police services in order for the perpetrators to be arrested and prosecuted. Furthermore, the sexually abused children will be offered psycho-social services by social workers, including, but not limited to counselling and placement to an alternative care if necessary. 


\subsection{Social Work Intervention}

In light of the realities that the scourge of sexual abuse continues to ravage and negatively affect the school learners, this section is dedicated on how social workers may intervene.

\subsubsection{Educate Learners}

Given the reported increase on the number of children that are sexually abused, it cannot be disputed that the need to educate children including school learners on sexual abuse is urgent and cannot and must not be postponed or delayed further. Manheim, Felicetti and Moloney (2019), indicate that it is necessary to provide children with information on sexual abuse as early as possible, and the advantage is that children will have information and skills on how to keep themselves safe. Since learners in the school are the main victims of sexual abuse, it is advisable that much focus on sexual abuse educational programs should be directed at them. Taking note of a plethora of social work methods of intervention such as case work, group work and community work, social workers after assment may decide on the best method that will best address the phenomenon of sexual abuse. For instance, in order to reach high number of learners, the group work method may be appropriate and social workers may conduct educational group work session's wich will provide learners with an opportunity to learn within a group context. Masilo (2018b) states the advantage of using group work as being intensive in nature and includes follow-up sessions that provide a platform for the evaluation of interventions by the social worker, and the performance of individual members and the entire group. According to Openshaw (2008, p.173) group work is a valuable practice tool for school social workers and almost any kind of problem can be addressed through group work. In educating learners, social workers should include not only girl learners, but also the boy learners who need to be educated on CSA.

\subsubsection{Establish and Strengthen the Childcare and Protection Forums}

The Republic of South Africa, like any other country, has the Constitution (Constitution of the Republic of South Africa Act 108 of 1996) which is the supreme law.This Constitution indicates the rights of childen, and for the purpose and relevance of discussions in this paper, include but not limited to the right to education; the right to an environment that is not harmful to health or wellbeing and the right to be protected from maltreatment, neglect, abuse, or degradation. It can be stated in this paper without any doubt, that those that are sexually abusing learners in South African schools are violating the constitutional rights of children and must be harshly punished. During the National Men's March on the 22 November 1997, the then President of South Africa, Mr Nelson Mandela said "Our children are our greatest treasure. They are our future. Those who abuse them tear at the fabric of our society and weaken nation" (Masilo, 2018b, p.44). The provision of the childcare and protection services flows directly from the Constitution of the Republic of South Africa 1996 (Act no. 108). By establishing and strengthening the childcare and protection forums in the school setting, social workers will be contributing towards a lasting solution in services that are aimed at safeguarding the best interests of the school learners. The childcare and protection forums should include relevant stakeholders such as the South African Policy Services, Department of Social Development, Department of Health, to name but few of the relevant stakeholders. Most importantly, the learners, parents and teachers should be the active participants in these forums. The childcare and protection forums will be responsible for identifying different problems encountered by learners, develop and implemented programmes and strategies for the purposes of intervention and prevention services.

\subsubsection{Engage Parents and Guardians}

Parents are the primary stakeholders in the education system as they are care givers to children. It is on this basis that it is argued in this paper that social workers need to engage parents and guardians of children as part of interventions in addressing CSA. The engagement of parents and guardians is important and necessary, especially given that research reveals that parents lack the ability to communicate with their children regarding child sexual abuse prevention topics (Guo, Chen, Yu, Jiang, Song \& Jin, 2019). The social workers may engage parents and guardians of children through focus group discussions and invidivual sessions. This will assist parents to identify any suspicious signs or symptoms of sexual abuse on their children, especially when bathing them at home. In instances where children are sexually abused, it is the parents and guardians that should provide care and support to the children. Vladimir and Robertson $(2019, \mathrm{p} .2)$, are of the view that family support and cohesion contribute to survivors' ability to cope with the aftermath of child sexual abuse in ways that protect their self-esteem, hopefulness, and positive attitude. Furthermore, envisaged engagement will help in enabling parents and guardians to have discussions with children not only on sexual abuse, but also matters such as teenage pregnancy and alcohol use. Lastly, it is hoped that this engagement will assist children in the early disclosure of sexual abuse incidents not only those that occurred at school but also home and community environments. 


\subsubsection{Facilitate Dialogues With School-Based Employees}

The social work profession has a role to carry out in the occupational setting. According to Zastrow (2017), social workers in the occupational setting might be involved in providing training and staff development programs. For the purpose of this paper, it is argued that social workers working in the school setting or rendering services to schools, need to facilitate dialogues that will target the school-based employees. This is due to the fact that CSA is not a learners' problem, but a problem of school-based employees who are perpetrating this crime against children. It is therefore imperative to take intervention measures to the school-based employees through dialogues. The dialogues will go a long way in the prevention of CSA against learners in schools. To achieve this purpose, it should be compulsory for the school-based employees to attend reasonably regular educational dialogues on sexual abuse. The dialogues should also be facilitated with the newly recruited school-based employees during the orientation and induction process. It is worthy to state that in terms of the South African laws, sexual abuse between teachers and learners is prohibited, irrespective of whether there is consent or not. As part of the dialogues, social workers should indicate to the school based employees that in terms of the law, they are obliged to report incidents of sexual abuse of learners perpetrated by other employees and should not turn a blind eye or overlook signs that clearly indicates that learners have been sexually abused.

\section{Conclusion}

Child sexual abuse is a serious social problem and a human rights violation in South Africa and elsewhere in the world. This paper has argued that CSA concerns the social work profession, and to this end, it is imperative that social workers should intensify their interventions in order to win the fight against this heinous crime against children. It is against this view that it is recommended that the proposed social work interventions be implemented in schools especially high-risk schools in order to contribute towards the prevention of CSA against learners. This paper further calls for the continuous design and implementation of CSA educational programs in schools by social workers. Lastly, it is recommended that the school social work programme be rolled out in all provinces in South Africa, and not only in selected provinces such as the Western Cape and KwaZulu Natal.

\section{Competing Interests Statement}

The authors declare that there are no competing or potential conflicts of interest.

\section{References}

Coetzee, S. (2018). Holding the state directly liable for educator-on-learner sexual abuse. Child Abuse Research: A South African Journal, 19(1), 30-44. Retrieved from https://journals.co.za/docserver/fulltext/carsa_v19_n1_a3.pdf?expires $=1568371071 \& \mathrm{id}=\mathrm{id} \&$ accname $=5783$ 7\&checksum=EA7D13C7F99A1D2350BC21584597E266

Dube, M. (2016). The psycho-social plight of widows in Binga District in Zimbabwe: The efficacy of social work intervention. (Thesis-PhD, Mahikeng, North West University). Retrieved from https://repository.nwu.ac.za/bitstream/handle/10394/24924/Dube_M.pdf?sequence=1

Guo, S., Chen, J., Yu, B., Jiang, Y., Song, Y., \& Jin, Y. (2019). Knowledge, Attitude and Practice of Child Sexual Abuse Prevention among Parents of Children with Hearing Loss: A Pilot Study in Beijing and Hebei Province, China. Journal of child sexual abuse, 28(7), 781-798. https://doi.org/10.1080/10538712.2019.1627688

Manheim, M., Felicetti, R., \& Moloney, G. (2019). Child sexual abuse victimization prevention programs in preschool and kindergarten: implications for practice. Journal of child sexual abuse, 1-13. https://doi.org/10.1080/10538712.2019.1627687

Markwei, U., \& Osei-Hwedie, K. (2019). Betrayed and Broken: A Study of the Experiences of Victims of Child Sexual Abuse in the Ga Community in Accra, Ghana. Journal of child sexual abuse, 28(4), 472-488. https://doi.org/10.1080/10538712.2019.1581869

Masehela, B. M. (2011). Exploring strategies for the prevention of sexual abuse at schools (Doctoral dissertation, University of Pretoria). Retrieved from https://pdfs.semanticscholar.org/ea48/6a4afaa3624122f5b55adcfc355db49a13a8.pdf

Masehela, B., \& Pillay, V. (2014). Shrouds of silence: A case study of sexual abuse in schools in the Limpopo Province in South Africa. Perspectives in Education, 32(3), 22-35. Retrieved from https://pdfs.semanticscholar.org/548e/a7f1 cf8d816dc0d92c719ba8c906d32a101d.pdf?_ga=2.230762271.16 81813513.1568800516-730220737.1563869365

Masilo, D. T. (2018). Prevention of Child Sexual Abuse within the Family System: Guidelines for an Educational 
Social Group Work Program. Journal of child sexual abuse, 27(4), 335-346. https://doi.org/10.1080/10538712.2018.1430089

Masilo, D. T. (2018b). Development of teenage pregnancy prevention model for learners in schools in North West Province: Implications for policy and practice considerations. (Thesis-PhD, Polokwane. University of Limpopo). http://hdl.handle.net/10386/2350

Muchacha, M., \& Mthetwa, E. (2015). Dynamics of child sexual abuse in Zimbabwe: Towards a socio-ecological framework of prevention. The Social Work Practitioner-Researcher, 27(1), 118-136. https://doi.org/10.25159/2415-5829/780

Muchanyerei, B. (2017). Apathy or fear? The role of social workers in Zimbabwe's political discourse. African Journal of Social Work, 7(2), 60-64. Retrieved from https://www.ajol.info/index.php/ajsw/article/view/165228/154688

Ngqakamba, S. (2019). Probe under way as 9-year old North West Curro pupil reports being raped in bathroom. Retrieved from https://www.news24.com/SouthAfrica/News/probe-under-way-as-9-year-old-north-westcurro-pupil-reports-being-raped-in-bathroom-20190220

Nicholson, G., \& Mafolo, K. (2019). Murder, sexual offences on the increase as grim statistics mount up. Retrieved from https://www.dailymaverick.co.za/article/2019-09-12-murder-sexual-offences-on-the-increase-as-grimstatistics-mount-up/

Openshaw, L. (2008). Social work in schools: Principles and practice. New York: The Guilford Press.

Phagane, T. (2019). Lesufi to visit Queens High School following sexual assault allegations. Retrieved from $\mathrm{http} / /$ www.sabcnews.com/sabcnews/lesufi-to-visit-queens-high-school-following-sexual-assault-allegations

Rule, D. M. (2017). Factors that influence the reporting of child sexual abuse amongst primary school teachers in South Africa: An application of the theory of planned behavior (Thesis- $\mathrm{PhD}$, Cape Town, University of Cape Town). Retrieved from https://open.uct.ac.za/bitstream/handle/11427/24926/thesis_hum_2017_ rule_deirdre_margo.pdf? sequence $=1$

Seleka, N. (2019). Pretoria primary school teacher suspended over sexual abuse claims. https://www.news24.com/SouthAfrica/News/pretoria-primary-school-teacher-suspended-over-sexual-abuseclaims-20190206

Scott, J. A. (2006). The role child sexual abuse can play in girl's involvement in prostitution (Dissertation Masters, Pretoria, University of Pretoria). Retrieved from http://hdl.handle.net/2263/22893

Singh, K. (2016). Alleged KZN sex tape teacher remains in custody. Retrieved from https://www.news24.com/SouthAfrica/News/alleged-kzn-sex-tape-teacher-remains-in-custody-20160829

The Citizen. (2019). 70 cases of sexual violence reported in Gauteng schools this year-Lesufi. Retrieved from https://citizen.co.za/news/south-africa/education/2166753/70-cases-of-sexual-violence-reported-in-gautengschools-this-year-lesufi/

Vladimir, M., \& Robertson, D. (2019). The Lived Experiences of Non-Offending Fathers with Children Who Survived Sexual Abuse. Journal of child sexual abuse, 1-21. https://doi.org/10.1080/10538712.2019.1620396

Zantsi, N. (2014). Beliefs and knowledge of isiXhosa speaking people about child sexual abuse in a rural area (Doctoral dissertation). Potchefstroom. North West University. Retrieved from https://pdfs.semanticscholar.org/1b70/a01fcf2d239d52a818dc427eabe621c1d3e9.pdf

Zastrow, C. (2017). Introduction social work and social welfare: Empowering people (12th ed.). USA. Cengage Learning.

\section{Copyrights}

Copyright for this article is retained by the author(s), with first publication rights granted to the journal.

This is an open-access article distributed under the terms and conditions of the Creative Commons Attribution license (http://creativecommons.org/licenses/by/4.0/). 